\title{
Application of dendrochronological analysis of Retama sphaerocarpa L. (Boiss) for dating agricultural abandonment
}

\section{AUTHORS}

\section{Marqués M.J. ${ }^{@}$ \\ mariajose.marques@ uam.es}

\section{Carral P.}

Álvarez-González

A.

Verdú I.

\section{Cantador S.}

\section{@ Corresponding Author}

Geology and

Geochemistry

Department.

Universidad Autónoma

de Madrid. C/ Francisco

Tomás y Valiente, 7 .

28049 Madrid, Spain.
Aplicación del análisis dedrocronológico de Retama sphaerocarpa L. (Boiss) para datar el abandono agrícola

Aplicação da análise dendrocronológica de Retama sphaerocarpa L. (Boiss) para datar o abandono de solos agricolas

Received: 03.11.2015 | Revised: 18.02.2016 | Accepted: 22.02.2016

\section{ABSTRACT}

Abandonment of agricultural land leads to changes in soil characteristics that may result in better or worse soil conditions. These changes are slow therefore the use of indicators for dating the time of abandonment is particularly useful. This study was carried out in Madrid, Spain with the aim to establish for the first time the use of Retama sphaerocarpa L. (Boiss) as a dendrochronological tool for dating land abandonment. This offers the possibility to take into consideration a period of time long enough for changes in soil to be determined. Such changes can be indicated by fluctuations in soil organic carbon content (SOC), porosity or water availability. Three different situations resulted from the dendrochronological analysis: soil currently tilled; soil recently abandoned (less than 5 years), and prolonged abandonment (in average 10 years). In addition the influence of Retama sphaerocarpa L. (Boiss) on soils was checked for these periods of abandonment. The rate of SOC gain can be considered fast. Tilled soils accounted for $0.48 \%$ SOC, and reached $1 \%$ in less than 5 years, although with wide standard deviations. Due to prolonged abandonment SOC reached $1.41 \%,(\mathrm{P}=0.09)$. Total soil porosity under tillage was $49 \%$, and decreased to $38 \%$ after $4-5$ years, but recovered to $41 \%$ under prolonged abandonment. Water availability (volumetric soil moisture between field capacity and permanent wilting point) remained the same, ranging from 7.7 to $8.5 \%$ along the whole period of time. The presence of $R$. sphaerocarpa $L$. (Boiss) accelerates soil changes as SOC in prolonged abandonment increased to $2.65 \%$, porosity was $41 \%$ and water availability $10.3 \%$.

\section{RESUMEN}

El abandono de las tierras agrícolas conduce a cambios en las características del suelo que pueden dar lugar a mejorar o empeorar las condiciones de suelo con el tiempo. Estos cambios son lentos, por lo que el uso de indicadores para datar el momento del abandono del laboreo es particularmente útil. Este estudio se llevó a cabo en Madrid (España) y establece por primera vez el uso de Retama sphaerocarpa L. (Boiss) como herramienta dendrocronológica para datar el abandono de las tierras. Esto of rece la posibilidad de calcular un periodo de tiempo suficiente para comprobar posibles cambios del suelo, tales como el contenido de carbono orgánico del suelo (COS), porosidad o la disponibilidad de agua. Tres situaciones diferentes surgen como resultado del análisis dendrocronológico: tierra labrada en la actualidad; suelo recientemente abandonado (menos de 5 años), y suelo con un abandono prolongado (en promedio 
10 años). Además se evaluó la influencia de la propia Retama sphaerocarpa L. (Boiss) en los suelos en estos periodos de abandono. La tasa de aumento de COS se puede considerar rápida. Los suelos labrados presentaron un 0,48\% de COS y un 1\% aquellos que llevaban menos de 5 años abandonados, aunque con elevada desviación estándar entre las muestras. Tras el abandono prolongado, el contenido de COS alcanzó un 1,41\%, (P=0,096). La porosidad total de los suelos labrados fue del 49\% y se redujo a 38\% después de 4-5 años de abandono, pero se recuperó al 41\% bajo el abandono prolongado. La disponibilidad de agua (bumedad volumétrica del suelo entre la capacidad de campo y el punto de marchitez permanente) sigue siendo la misma, entre 7,7 y 8,5\% a lo largo de todo el periodo de tiempo de estudio. La presencia de R. sphaerocarpa L. (Boiss) aceleró cambios en el suelo que fueron patentes en el abandono prolongado donde, por ejemplo, el contenido de COS alcanzó un valor de 2,65\%, la porosidad un $41 \%$ y la disponibilidad de agua un 10,3\%.

\section{RESUMO}

O abandono de terrenos agrícolas conduz a mudanças nas características do solo que podem resultar em melhores ou piores condiçôes deste ao longo do tempo. Estas mudanças são lentas e, como tal, o uso de indicadores para datar o momento do abandono da lavoura é particularmente útil. Este estudo foi realizado em Madrid, Espanha, $e$ estabelece pela primeira vez o uso de Retama sphaerocarpa L. (Boiss) como uma ferramenta para a avaliação dendrocronológica do intervalo de tempo desde o abandono das terras. Tal facto oferece a possibilidade de estimar o periodo necessário para verificar as alteraçôes nas características do solo, tais como o teor de carbono orgânico no solo (SOC), a porosidade ou a disponibilidade de água. Três situaçôes diferentes resultaram da análise dendrocronológica: solo atualmente cultivado; solo abandonado recentemente (menos de 5 anos), e abandono prolongado (em média, 10 anos). Para além disso, a influência de Retama sphaerocarpa L. (Boiss) no solo foi testada para estes periodos de abandono. A taxa de recuperação do SOC pode ser considerada rápida. Os solos cultivados apresentaram 0,48\% SOC, que aumentou para 1\% em menos de 5 anos, embora esta diferença não seja estatisticamente significativa. Com o abandono prolongado, o SOC atingiu 1,41\%, $(P=0,09)$. A porosidade do solo cultivado foi de 49\%, e diminuiu para 38\% após 4-5 anos de abandono, mas recuperou para $41 \%$ sob abandono prolongado. A disponibilidade de água (bumidade volumétrica do solo entre a capacidade de campo e o coeficiente de emurchecimento) permaneceu a mesma, entre 7,7 e 8,5\% ao longo de todo o periodo de tempo considerado. A presença de R. sphaerocarpa L. (Boiss) acelerou as mudanças no solo, tais como o como SOC que atingiu 2,65\% sob abandono prolongado, situação em que a porosidade foi de $41 \%$ e a disponibilidade de água de 10,3\%.

\section{Introduction}

The agricultural sector in Spain has experienced a continuous decline over the past decades. In the sixties there was 16.2 Mha of arable land, but currently there are only about 12 Mha, roughly the $25 \%$ of the country area (FAOSTAT 2014). Land use strongly affects soil conservation. With regard to agriculture this influence depends on the kind of crop, management practice and frequency of tillage. After decades or centuries of agricultural use, soils can be exhausted or vulnerable to erosion, drought or physical degradation. The evolution of soils after agricultural abandonment is of concern (García-Ruíz and LanaRenault 2011). Several authors have published study cases resulting in soil degradation after abandonment (Dunjó et al. 2003; Ries and Hirt 2008), but others have reported the recovery of soil properties (Atallah et al. 2015; Post and Known 2000). Due to this uncertainty, it is relevant to study soil property changes and its velocity after abandonment at local level. 
Many factors can be indicators of soil conservation; from the agricultural point of view the most frequently used are chemical analysis such as cation exchange capacity, $\mathrm{pH}$, nutrients, particularly $\mathrm{N}, \mathrm{P}$ and $\mathrm{K}$, and soil organic matter (Haynes 2005; Allen et al. 2011). There are other structural parameters like aggregate stability (Amezketa 1999), or porosity (Reynolds et al. 2009) amongst others. When the analysis of these factors yield positive results we consider that important soil properties like aeration, permeability and water or nutrient holding capacity are guaranteed, and therefore their derived ecosystem services will be preserved. Nevertheless, the evolution of these parameters is usually very slow, taking several decades to be acknowledged (Kosmas 2000; Holling et al. 2002; Reynolds et al. 2007). So, long term research projects would be needed to figure out changes after land abandonment. This is why the use of chronological indicators is particularly useful in pedology.

Fast growing pioneer species are commonly found in abandoned agricultural landscapes; most of them are annual and perennial herbaceous plants, but there are also several woody shrubs. The age of these shrubs can be used for dating the minimum time of land abandonment following dendrochronological techniques. This discipline is based on the relationship between tree-rings and meteorological years (Stokes and Smiley 1968; Fritts 1976). A cross-section of a tree or shrub often shows a distinct pattern of concentric tree rings. In climates having marked differences between seasons such as the Mediterranean climate, there are clear signs of the dark late wood that grows at the end of the previous year and the relatively pale early wood that grows at the start of the next year; therefore in this climate it is usual to have only one annual ring per year (Terradas and Savé 1992; Cherubini et al. 2003). Not all the species show these changes clearly; Quercus and Pinus trees are widely used for these purposes (Campelo et al. 2009). Consequently many studies are found in the literature with these genera for multiple applications of tree-ring dating, usually to study climate (Fonti and Jansen 2012), droughts (Fernández-de-Uña et al. 2013) or fires (Grissino-Mayer 2001).
In this study we introduce the use of Retama sphaerocarpa $L$. (Boiss) for dendrochronological purposes ( $R$. sphaerocarpa from now onwards). This leguminous shrub is frequent in abandoned plots in semi-arid Spanish landscapes (Pugnaire et al. 2006), and may be found in many different soil types (Talavera et al. 1999). There are well known positive effects of this species on herbaceous biodiversity thanks to its scarce foliage allowing light and water to reach the soil, and on nitrogen soil enrichment typical of leguminous plants (Caravaca et al. 2003; Rodríguez-Echeverría and Pérez-Fernández 2003). Nevertheless, there are no references about the dendrochronological use of this species in articles collected in peer-reviewed journals cited in Science Citation Index. There is only one study regarding climatic variations and ring growth (Paton et al. 2010).

This paper is intended to assess the suitability of $R$. sphaerocarpa to date land abandonment and subsequently the study of the evolution of soil parameters that are indicators of soil quality. Changes in soil bulk density, soil organic carbon and water holding capacity are analysed in soils currently tilled, and after five to fifteen years of abandonment in order to know the positive or negative consequences of abandonment and the velocity of these changes.

\section{Material and Methods}

\subsection{Study area}

The area of study is a mosaic of unfenced agricultural plots near Madrid, Spain, in a gentle rolling area covering approximately 50 ha (geographical coordinates at the centre of the area: $40.546331 \mathrm{~N},-3.667176 \mathrm{~W}$; European Datum).

These Luvisols (IUSS Working Group WRB 2015) over arkosic geology (Carral et al.1996) 
are located in the Tagus river basin at 715 m.a.s.l. where the topography is shaped by small creeks that are usually dry. The annual rainfall is around $400 \mathrm{~mm}$ and the average temperature is $13.7^{\circ} \mathrm{C}$ (data from the National Institute of Meteorology). The exact land management history of each plot is not available although until the 80's the whole area was used for rain-fed grain legume cereal intercropping, particularly the traditional chickpea, with marginal use as grassland. Currently a few plots are still being tilled by owners, most plots are abandoned and extensive grazing has become the predominant use as sheep flocks graze daily in the area.

\subsection{Sampling}

Sampling was organised according to the presence or absence of $R$. sphaerocarpa in the agricultural plots. These shrubs are randomly distributed in the area and have a scarce coverage, less than $10 \%$. We assumed that old specimens indicated longer abandonment of agricultural plots; young specimens indicated recent abandonment and absence of shrubs indicated current soil tillage.

$R$. sphaerocarpa is a large evergreen shrub having in average $3 \mathrm{~m}$ height and $3 \mathrm{~m}$ width formed by numerous branches whose radius can measure up to $5 \mathrm{~cm}$. It can live for 25 years (Pugnaire 1996; López et al. 2001). The selection of shrubs was made by a systematic randomized system: we collected 5 young shrubs (Re-Yo) and 5 mature shrubs (Re-Ma) in order to cover long periods of time. Based on a previous pilot sampling, we considered a priori that young shrubs measured less than $1 \mathrm{~m}$ height. In each shrub two larger branches were selected and sampled. These branches were diametrically opposed in the canopy. The branches were cut at 10 to $30 \mathrm{~cm}$ above the ground.

Composite soil samples were collected under each shrub (U-Re) and at $5 \mathrm{~m}$ around each shrub (A-Re). These soils around shrubs were covered by herbaceous vegetation. For these latter samples, composite soil samples consisted of 4 aliquots collected at the ends of a cross having $4 \mathrm{~m}$ long. Approximately $1 \mathrm{~kg}$ of topsoil (up to $15 \mathrm{~cm}$ depth) was collected in each case. In addition 5 soil samples were collected following the same scheme in areas of current tillage practice (Till), in these soils there was scarcer herbaceous vegetation. The total number of samples was 25, i.e. 5 under young shrubs (U-Re-Yo); 5 around young shrubs (A-Re-Yo); 5 under mature shrubs (U-Re-Ma); 5 around mature shrubs (A-Re-Ma) and 5 in soil currently tilled (Till). Soil samples were air dried at the laboratory for 2 weeks and further sieved $(<2 \mathrm{~mm})$.

\subsection{Dating with Retama sphaerocarpa L. (Boiss)}

All branches were cut again to obtain sections 2-3 cm wide, and these sections were then polished. Four different types of sandpapers were successively used 180, 400, 800, and 1200 grains per square inch. Polished sections were then scanned with high resolution (scanner Lexmark X4550) to magnify ring images (Adobe ${ }^{\circledR}$ Photoshop ${ }^{\circledR}$ ) and facilitate its counting on the screen (García González et al. 2001).

Rings may have some rough spots such as double rings, disappearance of part of the rings or different thickness (Gutiérrez 1985). In order to avoid errors resulting from these irregularities, counting the number of rings in several axes of sections is required. The use of at least two branches of each plant is also convenient to make comparisons between them. In case of difficulty in determining rings or if there are significant differences between the number of rings, the species must be discarded for dendrochronological studies.

Shrub rings were counted in 4 radiuses per section (Gutiérrez 1985; Pilcher 1990) starting from the outer to the inner ring as proposed by Yamaguchi (1990), cited in Ribas-Matamoros (2006). The outer ring corresponds to the year 2014 in this study. In order to test the uniformity of ring distribution a dispersion index (D) was 
used. It is based on the relationship established between the variance $\left(\mathrm{s}^{2}\right)$ and the mean $(\overline{\mathrm{x}})$ of data distribution (Southwood 1978; Eq.1). The inverse of dispersion yields the uniformity, considering that when $U=100 \%$ there is an absolute uniformity between data. Following uniformity criteria of Christiansen (1941), results from 85-90 are considered good, and more than $90 \%$ are considered excellent.

(Eq.1) $\quad U=1-\left(\frac{s^{2}}{\bar{X}}\right)$

\subsection{Soil variables}

Soil texture was determined by the Bouyoucos hydrometer method (Bouyoucos 1962) obtaining the percentage of clay $(<2 \mu \mathrm{m})$, silt $(2-50 \mu \mathrm{m})$ and sand (50-2000 $\mu \mathrm{m})$, according to the USDA system; two replicates per sample were performed. Electrical conductivity and $\mathrm{pH}$ were measured by potentiometric methods in volume ratios $1: 5$ and $1: 2.5 \mathrm{w} / \mathrm{v}$ respectively according to standard methods (MAPA 1994); two replicates per sample were performed. Total porosity was calculated from bulk density (Eq. 2) which was estimated by immersion of soil aggregates ( 2 to $3 \mathrm{~cm}$ diameter) in mercury (Haines 1923); five

$$
\text { (Eq.2) } \quad \mathrm{PT}=\left\{1-\left(\frac{B D}{P D}\right)\right\}
$$

replicates per sample were performed.

where

PT: total porosity (\%)

BD: bulk density $\left(\mathrm{g} \mathrm{cm}^{-3}\right)$

PD: Particle density, considering $2.65 \mathrm{~g} \mathrm{~cm}^{-3}$

Soil organic matter was estimated by the Walkley and Black method (1934). Soil organic carbon (SOC) was then calculated by the Van Bemmelen factor considering that $58 \%$ of soil organic matter is SOC. Organic carbon stock was calculated considering soil depth, bulk density and percentage of rock fragments according to the Eq.3.
(Eq.3) $\quad \mathrm{SOC}=\% \mathrm{OC} \times \mathrm{BD} \times \mathrm{d} \times(1-\mathrm{R}) \times 0.1$

where

SOC: Organic carbon stock $\left(\mathrm{kg} \mathrm{m}^{-2}\right)$

$\% O C$ : Soil organic carbon (\%)

BD: bulk density $\left(\mathrm{g} \mathrm{cm}^{-3}\right)$

d: soil depth $(\mathrm{m})$

R: rock fragments (\%)

Water holding capacity was determined by pedotransfer functions considering SOC, texture and bulk density (Saxton and Rawls 2006) in the 25 soil samples. In order to test the accuracy of such estimation, several experimental measurements were carried out using a Hyprop apparatus. This appliance uses two precision mini-tensiometers to measure water potential at different levels within an intact soil sample. The sample progressively dries, and changes in water potential can be correlated to changes in soil moisture content using the evaporation method (Peters and Durner 2008) and Tensioview software. Soil water retention curves were fitted using the bimodal van GenuchtenMualem equation (Durner 1994). Duplicated undisturbed soils were used; soils came from plots currently tilled, soils recently abandoned and soils under mature shrubs; two replicates per situation were performed.

\subsection{Data treatment}

Data were analysed by Statistica 6.1 software. Due to the small number of data, non-parametric tests were used. The Kruskall-Wallis (KW) test is a similar to a parametric one-way ANOVA, performed on ranks rather than means. Post-hoc comparisons of mean ranks of all pairs of groups were computed to find out significant differences between situations (Siegel and Castellan 1988, p. 213). Spearman $R$ was also computed from ranks to establish non-parametric correlations between variables (Gibbons 1985). 
Table 1. Mean, variance and uniformity of shrub-rings in R. sphaerocarpa in four orthogonal radiuses

\begin{tabular}{|c|c|c|c|c|c|c|c|}
\hline \multicolumn{8}{|c|}{ Number of rings } \\
\hline & radius & radius & radius & radius & \multirow[b]{2}{*}{ Mean } & \multirow[b]{2}{*}{ Variance } & \multirow[b]{2}{*}{ Uniformity } \\
\hline & 1 & 2 & 3 & 4 & & & \\
\hline \multicolumn{8}{|l|}{$\begin{array}{l}\text { Young shrubs } \\
\text { Mean age: } 4 \text { yr old }\end{array}$} \\
\hline 1 branch 1 Re-Yo 1.1 & 3 & 4 & 3 & 4 & 3.5 & 0.3 & $90 \%$ \\
\hline branch 2 Re-Yo 1.2 & 5 & 5 & 4 & 4 & 4.5 & 0.3 & $93 \%$ \\
\hline 2 branch 1 Re-Yo 2.1 & 3 & 2 & 2 & 3 & 2.5 & 0.3 & $87 \%$ \\
\hline branch 2 Re-Yo 2.2 & 3 & 3 & 3 & 3 & 3.0 & 0.0 & $100 \%$ \\
\hline 3 branch 1 Re-Yo 3.1 & 3 & 3 & 3 & 3 & 3.0 & 0.0 & $100 \%$ \\
\hline branch 2 Re-Yo 3.2 & 3 & 3 & 2 & 3 & 2.8 & 0.3 & $91 \%$ \\
\hline 4 branch 1 Re-Ma 6.1 & 6 & 6 & 6 & 6 & 6.0 & 0.0 & $100 \%$ \\
\hline branch 2 Re-Ma 6.2 & 6 & 6 & 6 & 6 & 6.0 & 0.0 & $100 \%$ \\
\hline 5 branch 1 Re-Yo 5.1 & 4 & 5 & 4 & 4 & 4.3 & 0.3 & $94 \%$ \\
\hline \multirow[t]{2}{*}{ branch 2 Re-Yo 5.2} & 5 & 5 & 4 & 5 & 4.8 & 0.3 & $95 \%$ \\
\hline & & & & & \multicolumn{2}{|c|}{ Uniformity average } & $95 \%$ \\
\hline \multirow{2}{*}{\multicolumn{8}{|c|}{$\begin{array}{l}\text { Mature shrubs } \\
\text { Mean age: } 10 \text { yr old }\end{array}$}} \\
\hline & & & & & & & \\
\hline 1 branch 1 Re-Ma 1.1 & 9 & 7 & 8 & 7 & 7.8 & 0.9 & $88 \%$ \\
\hline branch 2 Re-Ma 1.2 & 7 & 7 & 6 & 7 & 6.8 & 0.3 & $96 \%$ \\
\hline 2 branch 1 Re-Ma 2.1 & 7 & 6 & 6 & 7 & 6.5 & 0.3 & $95 \%$ \\
\hline branch 2 Re-Ma 2.2 & 7 & 7 & 7 & 7 & 7.0 & 0.0 & $100 \%$ \\
\hline 3 branch 1 Re-Ma 3.1 & 14 & 11 & 11 & 14 & 12.5 & 3 & $76 \%$ \\
\hline branch 2 Re-Ma 3.2 & 10 & 11 & 12 & 11 & 11.0 & 0.7 & $94 \%$ \\
\hline 4 branch 1 Re-Ma 4.1 & 11 & 10 & 11 & 11 & 10.8 & 0.3 & $98 \%$ \\
\hline branch 2 Re-Ma 4.2 & 11 & 10 & 9 & 11 & 10.3 & 0.9 & $91 \%$ \\
\hline 5 branch 1 Re-Ma 5.1 & 13 & 11 & 11 & 11 & 11.5 & 1.0 & $91 \%$ \\
\hline \multirow[t]{2}{*}{ branch 2 Re-Ma 5.2} & 13 & 10 & 11 & 11 & 11.3 & 1.6 & $86 \%$ \\
\hline & & & & & \multicolumn{2}{|c|}{ Uniformity average } & $92 \%$ \\
\hline
\end{tabular}

\section{Results}

3.1. Shrub-rings in Retama sphaerocarpa $L$. (Boiss)

The oldest shrub found in this study was 15 years old; this is therefore the period of time considered to study the evolution of soil variables. Table 1 shows results obtained in each branch, having two branches per plant. Rings are counted in four orthogonal radiuses to evaluate the corresponding uniformity. One year, corresponding to the core of the branch, must be added to these results to calculate the age of the shrub.
One shrub that was considered "a priori" as young due to its height (less than $1 \mathrm{~m}$ ) had 6 rings, (Table 1, Re-Ma 6), therefore it was re-assigned in the mature shrubs group. This change in the number of data does not affect statistical treatments as $\mathrm{KW}$ test does not analyse mean deviations but deviations of groups of medians and ranks (Olejnik and Algina 1987).

There were slight differences in the number of rings between different branches of the same plant, particularly in mature shrubs. Figure 1 shows the example of mature R. sphaerocarpa number 3 , 

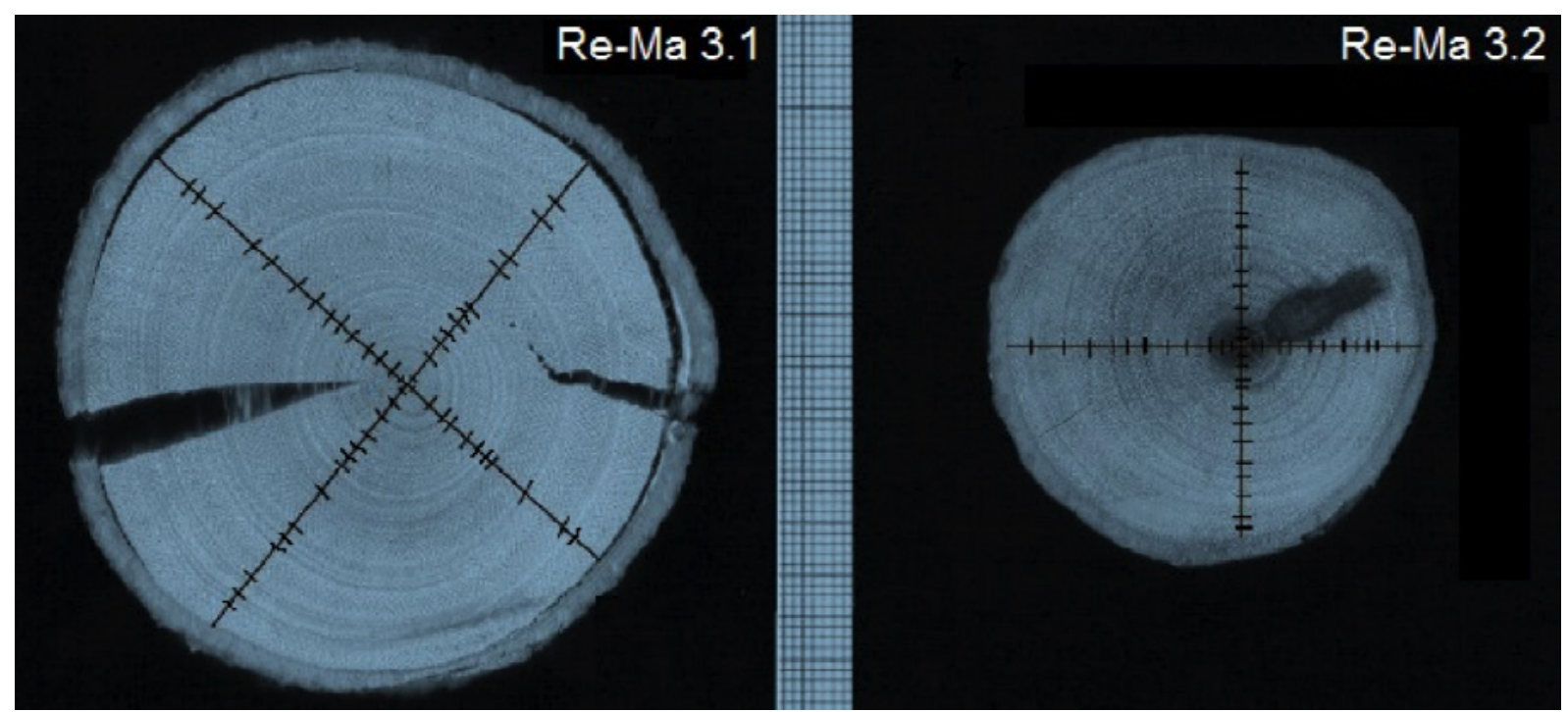

Figure 1. Four axes and counting number of rings in Retama sphaerocarpa. These two branches belong to the same shrub, the number of rings is unequal in this case.

having the most pronounced differences in this study. This case had the lowest uniformity $(76 \%$, Table 1), however, the global average was $90 \%$ which is considered as excellent uniformity.

\subsection{Soil characteristics}

Soil texture and physical-chemical analyses are shown in Table 2. There were no significant differences according to the $\mathrm{KW}$ test, therefore these variables were similar for all the sampling sites. Soils were slightly acid, $\mathrm{pH}$ was around 6.3 , having low electrical conductivity and sandy loam texture.

\subsection{Water holding capacity}

The comparison between pedotransfer functions and evaporation method results is shown in Figure 2. Considering the range of water availability, established between 2.54 and 4.2 $\mathrm{pF}$, both methods show a clear increase in volumetric moisture for soils under mature shrubs (U-Re-Ma). However, the evaporation method discriminates better the difference between tilled soils (Till) and recently abandoned soils (A-Re-Yo). Moreover moisture figures obtained by pedotransfer functions are usually higher than those obtained by evaporation method.

Table 2. Median, first and third quartile of soil physical-chemical characteristics of the study area. The Kruskal-Wallis statistic test $(\mathrm{H})$ showed that the groups of samples were not significantly different from each other $(p>0.05 ; N=25)$

\begin{tabular}{lccc} 
& Median & Q 25\% & Q 75\% \\
\hline Sand (\%) & 80.3 & 77.2 & 84.4 \\
\hline Clay (\%) & 13.4 & 11.4 & 16.1 \\
\hline Silt (\%) & 5.5 & 4.7 & 7.0 \\
\hline $\mathrm{pH}$ & 6.3 & 5.9 & 6.6 \\
\hline EC (dS/m) & 0.09 & 0.07 & 0.10 \\
\hline Bulk density $\left(\mathrm{g} \mathrm{cm}^{-3}\right)$ & 1.55 & 1.36 & 1.62 \\
\hline
\end{tabular}




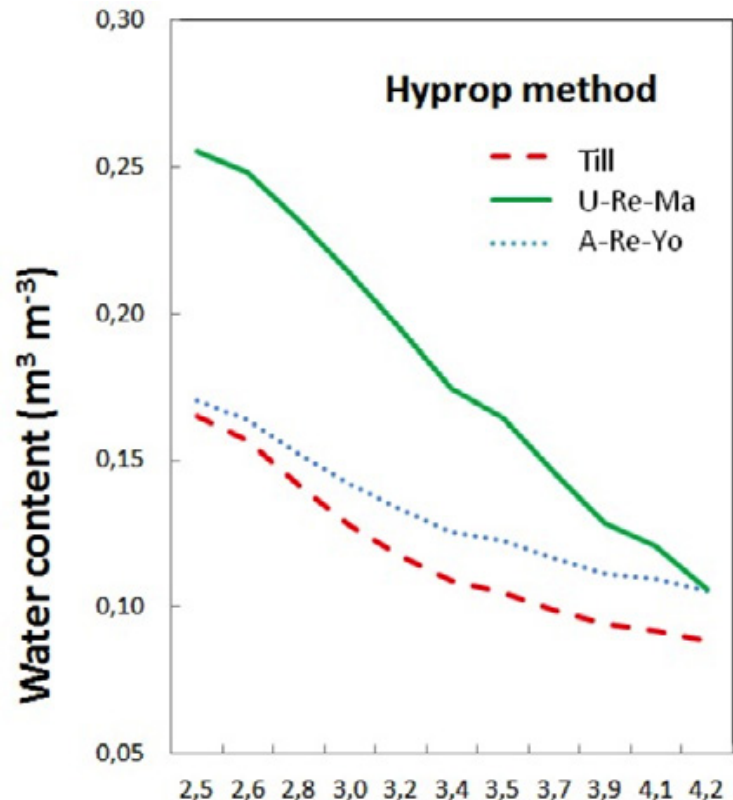

$\mathrm{pF}$

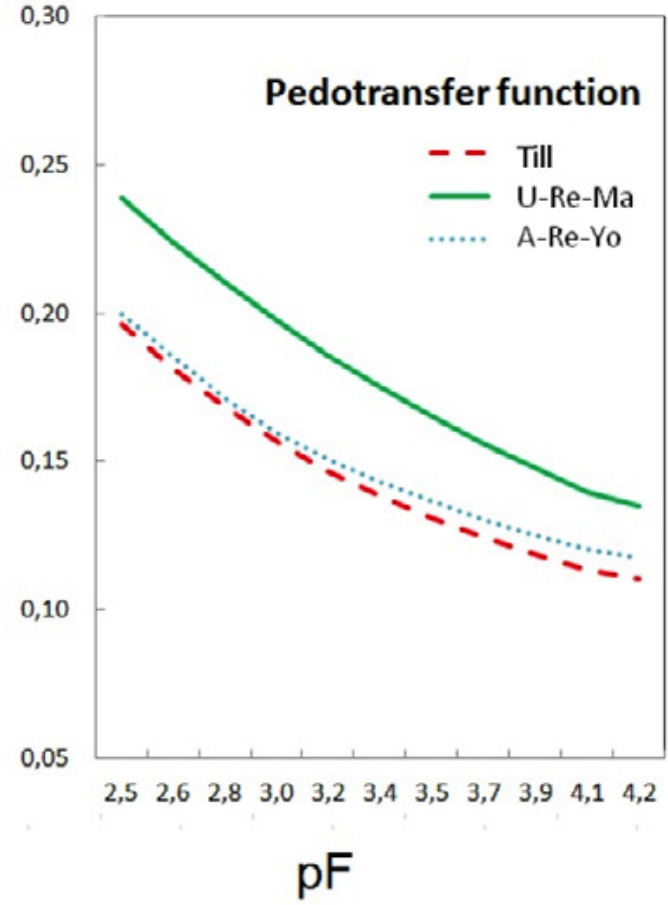

Figure 2. Water retention measured by evaporation method (left; $\mathrm{N}=2$ ) and estimated from pedotransfer functions (right; $\mathrm{N}=5$ ). Till: soils currently tilled. A-Re-Yo: soils recently abandoned. U-Re-Ma: soils under mature $R$. sphaerocarpa.

Total available water calculated by evaporation method was: $8 \%, 7 \%$ and $15 \%$ for tilled soils, recently abandoned soils and soils under mature shrubs respectively. In turn, the figures estimated by pedotransfer functions were $9 \%$, $8 \%$ and $10 \%$ respectively.

\subsection{Analysis of soil variations with time}

Table 3 shows results of $\mathrm{KW}$ analysis and the corresponding statistical significance for soil variables. In most cases there were unequal variances, therefore significant differences were computed by multiple comparisons of mean ranks. Differences were highly significant for SOC $(p<0.01)$. Other variables such as porosity or water availability were not significantly different globally although there were differences between particular situations. SOC was higher under mature shrubs (Median $(\mathrm{Me})=2.85 \%$ ). Soils around mature shrubs also had higher SOC $(1.41 \%)$, but its variability impeded to establish statistical differences between these soils and those recently or currently tilled, despite having SOC less than $1 \%$.
Soils under mature shrubs have higher SOC than soils under young shrubs ( $p=0.009)$, and this difference is more remarkable compared with soils around young shrubs $(p=0.002)$ and soils currently tilled $(p<0.0001)$. There is a significant correlation between SOC and the number of years of abandonment $(R$ Spearman $=0.70$ $(p<0.05))$. Figure 3 shows this relationship along time, being this time estimated from the rings of the shrubs. In this figure soils under young shrubs are identified by " $r$ " and soils under mature shrubs are identified by "R".

As mentioned, there is no difference between soils under young shrubs and soils currently tilled. This may mean that four years, that is the maximum age of these young shrubs, are not enough to improve organic carbon content in these soils.

Soils currently tilled show the highest total porosity ( $\mathrm{Me}=49 \%$ ) due to physical break of aggregates. When tillage is no longer practiced, there is a significant decrease of porosity for soils recently abandoned ( $\mathrm{Me}=38-40 \%$, Table 3 ). Some years 
Table 3. Differences found between soil situations. KW-H: Kruskal Wallis test. SOC: Soil Organic Carbon. FC: Field Capacity; PMP: Permanent Wilting Point. AW: Total Water Available

\begin{tabular}{|c|c|c|c|c|c|c|}
\hline \multicolumn{7}{|c|}{$\operatorname{SOC}(\%) \cdot K W-H(4.25)=16 \cdot 4 \cdot p=0.003$} \\
\hline & Median & Q25-Q75 & Till & U-Re-Yo & A-Re-Yo & U-Re-Ma \\
\hline Till & 0.48 & $0.47-0.78$ & & & & \\
\hline U-Re-Yo & 1.00 & $0.88-1.71$ & 1.000 & & & \\
\hline A-Re-Yo & 0.98 & $0.84-1.16$ & 1.000 & 1.000 & & \\
\hline U-Re-Ma & 2.85 & $2.36-3.10$ & $0.000^{* *}$ & $0.009^{* *}$ & $0.002^{* *}$ & \\
\hline A-Re-Ma & 1.41 & $1.31-1.82$ & 0.096 & 0.809 & 0.325 & 1.000 \\
\hline \multicolumn{7}{|c|}{ Rock fragment fraction (\%). $K W-H(4.25)=13.5 . p=0.009$} \\
\hline & Median & Q25-Q75 & Till & U-Re-Yo & A-Re-Yo & U-Re-Ma \\
\hline Till & 24.0 & $24.0-25.8$ & & & & \\
\hline U-Re-Yo & 12.3 & $11.9-13.0$ & $0.001^{* *}$ & & & \\
\hline A-Re-Yo & 12.7 & $11.7-12.7$ & $0.001^{* *}$ & 1.000 & & \\
\hline U-Re-Ma & 12.9 & $10.2-14.9$ & 0.310 & 1.000 & 1.000 & \\
\hline A-Re-Ma & 14.9 & $13.2-16.1$ & 1.000 & 0.498 & 0.546 & 1.000 \\
\hline \multicolumn{7}{|c|}{ Total Porosity (\%). KW-H(4.25)= 7.01. $p=0.13$} \\
\hline & Median & Q25-Q75 & Till & U-Re-Yo & A-Re-Yo & U-Re-Ma \\
\hline Till & $49 \%$ & $49.2-49.5$ & & & & \\
\hline U-Re-Yo & $40 \%$ & $35.6-44.7$ & $0.039^{*}$ & & & \\
\hline A-Re-Yo & $38 \%$ & $36.9-40.1$ & $0.013^{*}$ & 1.000 & & \\
\hline U-Re-Ma & $39 \%$ & $37.8-47.6$ & 1.000 & 1.000 & 1.000 & \\
\hline A-Re-Ma & $41 \%$ & $34.7-45.9$ & 1.000 & 1.000 & 1.000 & 1.000 \\
\hline \multicolumn{7}{|c|}{ Vol. Soil Moisture at FC (\%). KW-H(4.25)=6.41. $p=0.17$} \\
\hline & Median & Q25-Q75 & Till & U-Re-Yo & A-Re-Yo & U-Re-Ma \\
\hline Till & $19.8 \%$ & $19-21$ & & & & \\
\hline U-Re-Yo & $20.2 \%$ & $19-21$ & 1.000 & & & \\
\hline A-Re-Yo & $19.8 \%$ & $18-20$ & 1.000 & 1.000 & & \\
\hline U-Re-Ma & $22.6 \%$ & $22-26$ & 0.207 & 0.121 & $0.019^{*}$ & \\
\hline A-Re-Ma & $19.2 \%$ & $17-21$ & 1.000 & 1.000 & 1.000 & 0.376 \\
\hline \multicolumn{7}{|c|}{ Volumetric Soil Moisture at PWP (\%). KW-H(4.25)= 5.28. $p=0.26$} \\
\hline & Median & Q25-Q75 & Till & U-Re-Yo & A-Re-Yo & U-Re-Ma \\
\hline Till & $10.9 \%$ & $10-13$ & & & & \\
\hline U-Re-Yo & $12.2 \%$ & $12-13$ & 1.000 & & & \\
\hline A-Re-Yo & $12.1 \%$ & $11-13$ & 1.000 & 1.000 & & \\
\hline U-Re-Ma & $12.4 \%$ & $12-16$ & 0.310 & 0.653 & 0.310 & \\
\hline A-Re-Ma & $11.1 \%$ & $9-11$ & 1.000 & 1.000 & 1.000 & 0.376 \\
\hline \multicolumn{7}{|c|}{ Total Available Water (FC-PMP). KW-H(4.25)= 6.5. $p=0.16$} \\
\hline & Median & Q25-Q75 & Till & U-Re-Yo & A-Re-Yo & U-Re-Ma \\
\hline Till & $8.5 \%$ & $8-9$ & & & & \\
\hline U-Re-Yo & $7.7 \%$ & $7-9$ & 1.000 & & & \\
\hline A-Re-Yo & $7.7 \%$ & $7-8$ & 1.000 & 1.000 & & \\
\hline U-Re-Ma & $10.3 \%$ & $10-11$ & 0.455 & $0.047^{*}$ & $0.013^{*}$ & \\
\hline A-Re-Ma & $8.4 \%$ & $7-10$ & 1.000 & 1.000 & 1.000 & 0.776 \\
\hline
\end{tabular}




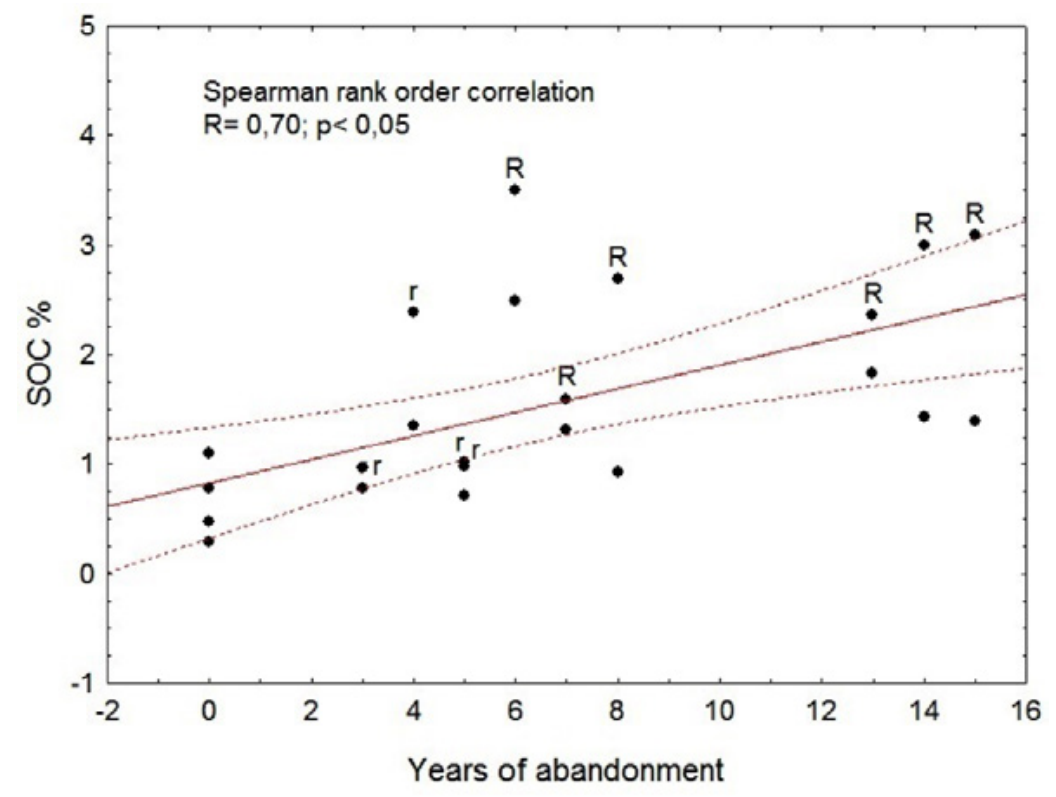

Figure 3. Evolution of soil organic carbon (SOC) content along 15 years. "•": soils currently tilled ( 0 years of abandonment) or having only herbaceous vegetation (A-Re); "r" soils beneath young $R$. sphaerocarpa (U-ReYo) and "R" soils beneath mature $R$. sphaerocarpa (U-Re-Ma).

later, in soils with prolonged abandonment, total porosity tend to increase $(\mathrm{Me}=39-41 \%)$ being statistically similar to currently tilled soil.

With regard to water availability there are no differences in volumetric moisture when soils are dry, at the permanent wilting point $(\mathrm{pF} 4.2 ; \mathrm{Me}=12 \%)$, however, there are punctual differences when soils are wet at field capacity ( $\mathrm{pF}$ 2.54); under these conditions soils beneath mature shrubs can hold more water than the rest of soils ( $\mathrm{Me}=22.6 \%$ ). Total available water (AW) obtained from the difference between moisture at field capacity and moisture at permanent wilting point, is affected by compaction when soils are considered as recently abandoned, being $7.7 \%$, even under young shrubs. From the statistical point of view, soils recently tilled have the same water available content than soils under prolonged abandonment, between 8.4 and $10.3 \%$.

\section{Discussion and Conclusions}

The cross-section of $R$. sphaerocarpa shows a distinct pattern of concentric tree rings with $90 \%$ uniformity that may be decreasing in old shrubs. Further research is needed in this species to clearly distinguish ring composition. Usually one annual ring is composed of a ring of early wood and a ring of late wood, nevertheless there are growth anomalies that lead to false rings or lack of rings. Such different growth pattern has been observed in this study, so the whole cross-section should be analysed to have an accurate interpretation of shrub rings (Cherubini et al. 2003). We also observed different number of rings from the largest branches of the same plant, therefore, several branches should be used to obtain accurate results. Considering these conditions, this species can be recommended for dendrochronological studies covering 25 years maximum, the age of oldest plants.

The experimental design allows us to establish three main situations: soils recently tilled, soils recently abandoned (4 years in average) and 
soils under more prolonged abandonment (10 years in average).

In this scenario, we concluded that soil tillage, practiced to prepare optimum soil conditions for crop growth, and valuable for weed and pest control, is leading to increased total porosity, but after tillage, soils tend to rapidly collapse having a high shrinkage ability, particularly if soil organic matter is low (Dörner et al. 2010) as is the case of this study. Agricultural soils in this region are "tillage-dependent" to maintain soil porosity. After abandonment, soils experience an increase in bulk density, from 1.32 to $1.60 \mathrm{~g} \mathrm{~cm}^{-3}$ (medians) in the first four to five years. When abandonment continues, bulk density diminishes to $1.50 \mathrm{~g}$ $\mathrm{cm}-3$. Soil porosity tend to recover in prolonged abandonment in this study, this may be due to SOC increase (Post and Known 2000), and root systems development (Fisher et al. 1994) from herbaceous vegetation in this case, that are able to increase particularly microporosity (Feeney et al. 2006) which contributes to create stable structure in soils (Czarnes et al. 2000). The management history of croplands can play an important role in the ability of soils to recover physical structure and vegetation (Standish et al. 2006) and, if available, plot history should be taken into account.

$\mathrm{SOC}$ is increasing gradually during abandonment; in this study prolonged abandonment results in SOC increase from $0.48 \%$ to $1.41 \%$ - in the absence of $R$. sphaerocarpa - the significance of this difference is $p=0.096$, higher than the usual $p=0.05$, but remarkable in any case.

Under these semi-arid climatic conditions, with frequent droughts, water plays a critical role. When soils are dry (permanent wilting point), volumetric moisture is similar for the whole area, being between 11 to $12 \%$. This may be due to the fact that soil moisture depends on the texture in this range of matric potential, being more independent from other factors such as macrostructure or soil organic matter (Wösten et al. 2001). Similarly, these soils are able to hold as maximum 19.2 to $19.8 \%$ of water (field capacity), no matter soil use or time of abandonment. As a result, total available water is ranging from 7.7 to
$8.5 \%$ for tilled or abandoned soils. This confirms the slowness of soil changes in Mediterranean climates (Romero Díaz 2003; Cuesta et al. 2012).

From the methodological point of view, soil water content results yielded by pedotransfer functions are in line with experimental measurements, although they were not exact enough to discriminate the effect of current tillage and recent abandonment as the evaporation method did. When there are slight differences between situations, experimental measurements, e.g. evaporation method, are recommended.

When shrubs are covering soils there are some differences. $R$. sphaerocarpa accelerates changes. Soils under young shrubs do not show higher SOC, porosity or available water when they are compared to tilled or recently abandoned soils, but soils under mature shrubs do. SOC is $2.85 \%$ (median) in these cases, significantly higher than $0.48 \%$ in tilled soils. If we consider 10 years as the average of abandonment, the rate of SOC gain was $0.2 \%$ per year. Considering this figure as carbon stock per square metre and $15 \mathrm{~cm}$ depth, this rate would be equivalent to $40 \mathrm{~g} \mathrm{C} \mathrm{m}^{-2} \mathrm{yr}^{-1}$. This figure is in line with the average values found in the review paper made by Post and Known (2000) analysing SOC gains arising after land use changes from croplands to grasslands ranging from 3.1 to $110 \mathrm{~g} \mathrm{C} \mathrm{m}^{-2} \mathrm{yr}^{-1}$.

If this rate would be maintained, soils may reach SOC concentrations found under old oak trees in the area (average 6\%, personal communication) in 30 years. Soils not having the influence of $R$. sphaerocarpa, show $0.09 \%$ annual SOC gain, therefore, they may need some 60 years to reach maximum organic carbon levels for soils in this area. Nevertheless, SOC gains are usually rapid the first years of abandonment, up to a decade, and tend to go down and stabilise further on (Martínez-Fernández et al. 1996; De Baets et al. 2013) therefore, these changes may need more time.

Other fields of research may be explored. When environmental conditions encourage growth, the plants may add extra tissue and produce thicker rings, and on the contrary, in a harsh year 
or season, growth is slowed and rings may be thinner. An interesting approach can consider the buffering influence of soils of high quality in such ring growth variations.

\section{REFERENCES}

-Allen DE, Singh BP, Dalal RC. 2011. Soil health indicators under climate change - a review of current knowledge. In: Singh BP, Cowie AL, Chan KY, editors. Soil Health and Climate Change. Soil Biology Series. Berlin, Heidelberg: Springer-Verlag. p. 25-45.

- Amezketa E. 1999. Soil aggregate stability: A review. J Sust Agric. 14:83-151.

- Atallah T, Sitt K, El Asmar E, Bitar S, Ibrahim L, Khatib MN, Darwish T. 2015. Effect of abandonment of olive orchards on soil organic carbon sequestration in Mediterranean Lebanon. Soil Res. 53(7):745-752.

- Bouyoucos GJ. 1962. Hydrometer method improved for making particle size analysis of soils. Agron J. 54:464465 .

- Campelo F, Nabais C, García-González I, Cherubini P, Gutiérrez E, Freitas H. 2009. Dendrochronology of Quercus ilex $L$. and its potential use for climate reconstruction in the Mediterranean region. Can J Forest Res. 39:2486-2493.

- Caravaca F, Alguacil MM, Figueroa D, Barea JM, Roldán A. 2003. Re-establishment of Retama sphaerocarpa as a target species for reclamation of soil physical and biological properties in a semiarid Mediterranean land. Forest Ecol Manage. 182:49-58.

- Carral MP, Martín-Serrano A, Goy JL, Zazo C. 1996. Las altas superficies del interfluvio de los ríos ManzanaresJarama al NE de Madrid (España). Caracterización geomorfológica y edáfica. Estudios Geol. 52:231-241.

- Cherubini P, Gartner BL, Tognetti R, Braker OU, Schoch W, Innes JL. 2003. Identification, measurement and interpretation of tree rings in woodyspecies from Mediterranean climates. Biol Rev. 78:119-148.

- Christiansen JE. 1941. Uniformity of application of water by sprinkler systems. Agric Eng., March:89-92.

- Cuesta B, Rey Benayas JM, Gallardo A, Villar-Salvador P, González-Espinosa M. 2012. Soil chemical properties in abandoned Mediterranean cropland after succession and oak reforestation. Acta Oecologica 38:58-65.

- Czarnes S, Hallett PD, Bengough AG, Young IM. 2000. Rootand microbial-derived mucilages affect soil structure and water transport. Eur J Soil Sci. 51:435-443.
- De Baets S, Meersmans J, Vanacker V, Quine TA, Van Oost K. 2013. Spatial variability and change in soil organic carbon stocks in response to recovery following land abandonment and erosion in mountainous drylands. Soil Use Manage. 29:65-76.

- Dörner J, Sandoval P, Dec D. 2010. The role of soil structure on the pore functionality of an ultisol. Soil Sci Plant Nutr. 10(4):495-508.

- Dunjó G, Pardini G, Gispert M. 2003. Land Use Change Effects on Abandoned Terraced Soils in a Mediterranean Catchment, NE Spain. Catena 52:23-37.

- Durner W. 1994. Hydraulic conductivity estimation for soils with heterogeneous pore structure. Water Resour Res. 30:211-223.

- FAOSTAT. 2014. http://faostat3.fao.org. Accessed October 2015.

- Feeney DS, Crawford JW, Daniell T, Hallett PD, Nunan N, Ritz K, Rivers M, Young IM. 2006. Three-dimensional microorganisation of the soil-root-microbe system. Microb Ecol. 52:151-158.

- Fernández-de-Uña L, Fonti P, Aranda I, Cañellas I, GeaIzquierdo G. 2013. Impact of Drought on the Intra-Annual Growth of Pinus sylvestris L. The Open Forest Sci J. 6 (Suppl 1 M3):43-45.

- Fisher MJ, Rao IM, Ayarza MA, Lascano CE, Sanz JI, Thomas RJ, Vera RR. 1994. Carbon storage by introduced deep-rooted grasses in the South American savannas. Science 371:236-238.

- Fonti P, Jansen S. 2012. Xylem plasticity in response to climate. New Phytol. 195:734-736.

- Fritts HD. 1976. Dendrochronology and Dendroclimatology. In: Tree Rings and Climate. London: Academic Press. p. $1-54$.

- García González I, García Rodríguez LG, Díaz Vizcaíno E. 2001. Empleo de un escáner de sobremesa para la medición manual de anillos de crecimiento. En: Actas del III Congreso Forestal Español; 2001 25-28 Sept; Granada, Spain.

- García-Ruiz JM, Lana-Renault N. 2011. Hydrological and erosive consequences of farmland abandonment in Europe, with special reference to the Mediterranean region-a review. Agr Ecosyst Environ. 140(3):317-338.

- Gibbons JD. 1985. Nonparametric statistical inference (2nd ed.). New York: Marcel Dekker.

- Grissino-Mayer HD. 2001. FHX2-Software for analyzing temporal and spatial patterns in fire regimes from tree rings. Tree-Ring Res. 57:115-124.

- Gutiérrez E. 1985. Variability of radius growth at 25 year old Pinus uncinata Miller ex Mirbel species in the Spanish North-East Pyrenees. Qüestió 9(2):95-104. 
- Haines WB. 1923. The volume changes associated with variations of water content in soil. J Agric Sci. 13:296-310.

- Haynes RJ. 2005. Labile organic matter fractions as central components of the quality of agricultural soils: an overview. Adv Agron. 85:221-268.

- Holling CS, Gunderson LH, Ludwig D. 2002. In quest of a theory of adaptive change. In: Gunderson LH, Holling CS, editors. Panarchy: Understanding Transformations in Human and Natural Systems. Washington, D.C.: Island Press. p. 3-22.

- IUSS Working Group WRB. 2015. World Reference Base for Soil Resources 2014, update 2015. International soil classification system for naming soils and creating legends for soil maps. World Soil Resources Reports No. 106. Rome: FAO.

- Kosmas C, Geronditis S, Marathianou M. 2000. The effect of land use change on soils and vegetation over various lithological formations on Lesvos (Greece). Catena 40(1):51-68.

- López F, Fungairiño SG, de las Heras P, Serrano JM, Acosta FJ. 2001. Age changes in the vegetative vs. reproductive allocation by module demographic strategies in a perennial plant. Plant Ecol. 157:13-21.

- MAPA. 1994. Métodos Oficiales de Análisis de Suelos y Aguas para Riego. Madrid: Ministerio de Agricultura, Pesca y Alimentación (Ed).

- Martínez Fernández J, Martínez Fernández J, López Bermúdez F, Romero Díaz A. 1996. Evolution of vegetation and pedological characteristics in fields with different age of abandonment: A case study in Murcia (Spain). In: Rubio JL, Calvo A, editors. Soil degradation and desertification in Mediterranean environments. Geoforma Ediciones. p. 279-290.

- Olejnik SF, Algina J. 1987. Type I error rates and power estimates of selected parametric and nonparametric tests of scale. J Educ Stat. 12:45-61.

- Paton D, Cuenca, J, Gala JA, Escudero JC. 2010. Dendroclimatology of two Mediterranean shrub species: Cistus ladanifer $L$. and Retama sphaerocarpa $L$. (Boiss). In: Mielikäinen $\mathrm{K}$, Mäkinen $\mathrm{H}$, Timonen $\mathrm{M}$, editors. Proceedings of the WorldDendro 2010. The 8th International conference on Dendrochronology; 2010 1318 Jun; Rovaniemi, Finland.

- Peters A, Durner W. 2008. Simplified Evaporation Method for Determining Soil Hydraulic Properties. J Hydrol. 356:147-162.

- Pilcher JR. 1990. Sample preparation, cross-dating and measurement. In: Cook ER, Kariukstis LA, editors. Methods of Dendrochronology. Applications in the environmental science. Dordrecht: Kluwer. p. 40-51.
- Post WM, Known KC. 2000. Carbon sequestration and land-use change: processes and potential. Global Change Biol. 6:317-328.

- Pugnaire FI, Haase P, Puigdefábregas J, Cueto M, Clark SC, Incoll LD. 1996. Facilitation and succession under the canopy of a leguminous shrub, Retama sphaerocarpa, in a semiarid environment in southeast Spain. Oikos 76:455-464

- Pugnaire FI, Luque M, Armas C, Gutierrez Carretero L. 2006. Colonization processes in semi-arid Mediterranean old-fields. J Arid Environ. 65:591-603.

- Reynolds WD, Drury CF, Tan CS, Fox CA, Yang XM. 2009. Use of indicators and pore volume function characteristics to quantify soil physical quality. Geoderma 152:252-263.

- Reynolds JF, Stafford Smith DM, Lambin EF, Turner II BL, Mortimore M, Batterbury SPJ, Downing TE, Dowlatabadi $\mathrm{H}$, Fernandez RJ, Herrick JE, Huber-Sannwald E, Jiang $\mathrm{H}$, Leemans R, Lynam T, Maestre FT, Ayarza M, Walker B. 2007. Global desertification: building a science for dryland development. Science 316(11):847-851.

- Ribas-Matamoros M. 2006. Dendrocronología de Pinus halepensis Mill. en el este de la Península Ibérica e islas Baleares: Sensibilidad y grado de adaptación a las condiciones climáticas. PhD thesis. Barcelona: Universidad de Barcelona. Available in: http://hdl.handle.net/2445/35321 (Accessed: 3 June 2015)

- Ries BR, Hirt U. 2008. Permanence of Soil Surface Crusts on Abandoned Farmland in the Central Ebro. Catena 72:282-296.

- Rodríguez-Echeverría S, Pérez-Fernández MA. 2003. Soil fertility and herb facilitation mediated by Retama sphaerocarpa. J Veg Sci. 14(6):807-814.

- Romero Díaz A. 2003. Influencia de la litología en las consecuencias del abandono de tierras de cultivo en medios mediterráneos semiáridos. Papeles de Geografía $38: 151-165$

- Saxton KE, Rawls WJ. 2006. Soil Water Characteristic Estimates by Texture and Organic Matter for Hydrologic Solutions. Soil Sci Soc Am J. 70:1569-1578.

- Siegel S, Castellan NJ. 1988. Nonparametric statistics for the behavioural sciences (2nd ed.). New York: McGraw-Hill.

- Southwood TRE. 1978. Dispersion. In: Ecological Methods, 2nd edition. New York: Wiley/Halsted. p. 26-57.

- Standish R, Cramer V, Hobbs R, Kobryn H. 2006. Legacy of land-use evident in soilsof Western Australia's wheatbelt. Plant Soil 280:189-207. 
- Stokes MA, Smiley TL. 1968. Tree-ring dating. Chicago: University of Chicago Press.

- Talavera S, Aedo C, Castroviejo S, Romero C, Sáez L, Salgueiro FJ, Velayos M. 1999. Leguminosae. In: Castroviejo S, coordinator. Flora Ibérica. Vol. VII. Real Jardín Botánico, Madrid: CSIC. p. 140.

- Terradas J, Savé R. 1992. The influence of summer and winter stress and water relationships on the distribution of Quercus ilex L. Vegetatio 99-100:137-145.

-Walkley A, Black IA. 1934. An Examination of Degtjareff Method for Determining Soil Organic Matter and a Proposed Modification of the Chromic Acid Titration Method. Soil Sci. 37:29-37.

- Wösten JHM, Pachpsky YaA, Rawls WJ. 2001. Pedotransfer functions: bridging the gap between available basic soil data and missing soil hydraulic characteristics. Journal of Hydrology 251:123-150.

- Yamaguchi DK. 1990. A simple method for cross-dating increment cores from living trees. Can J Forest Res. 21:414-416. 